\title{
Adaptation of Small-Scale Tea and Coffee Farmers in Kenya to Climate Change
}

\author{
Alice Nyawira Karuri
}

\section{Contents}

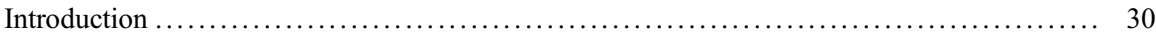

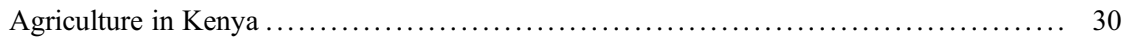

Climate Change Policies and Regulations in Kenya ............................ 31

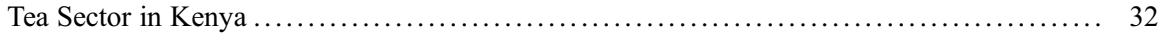

Climate Change Challenges in the Tea Sector ............................... 34

Adaptation and Mitigation Measures by Small-Scale Farmers in the Tea Sector........ 34

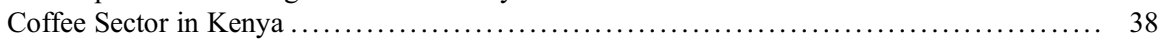

Climate Change Challenges in the Coffee Sector ............................. 39

Adaptation and Mitigation Measures by Small-Scale Farmers in the Coffee Sector ....... 40

Recommendations and Conclusion ............................................ 42

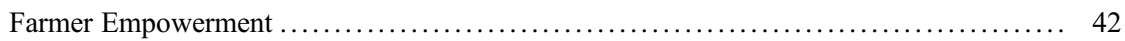

Strengthening of Institutions . . . . . . . . . .

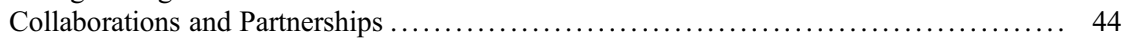

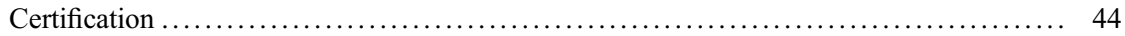

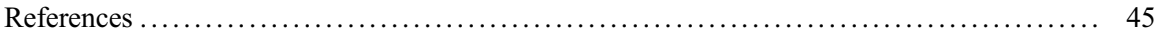

\section{Abstract}

The adverse effect of climate change on agriculture is well-documented and is a cause of concern for governments globally. In addition to concerns over food crop production, the economies of numerous developing countries rely heavily on cash crops. The coffee and tea sectors are key in Kenya's economy, contributing significantly to the gross domestic product, foreign exchange, and the direct or

This chapter was previously published non-open access with exclusive rights reserved by the Publisher. It has been changed retrospectively to open access under a CC BY 4.0 license and the copyright holder is "The Author(s)". For further details, please see the license information at the end of the chapter.

A. N. Karuri $(\bowtie)$

School of Humanities and Social Sciences, Strathmore University, Nairobi, Kenya

e-mail: akaruri@strathmore.edu 
indirect employment of millions. Farmers engaged in the production of coffee and tea are predominantly small-scale farmers, with the majority farming on less than five acres. Climate change poses a threat to the production of these two crops and by extension to the economy of Kenya and the livelihood of farmers and those employed in these sectors. This study identifies the challenges posed by climate change in the tea and coffee sectors, the adaptation and mitigation measures identified, and the scope of their implementation. The production, processing, and marketing of tea and coffee in Kenya differs widely in terms of the institutions and institutional arrangements in the two sectors. This study will therefore analyze the role played by institutions in both sectors and how this affects climate change adaptation and mitigation measures by small-scale farmers.

\section{Keywords}

Kenya $\cdot$ Tea $\cdot$ Coffee $\cdot$ Small-scale farmers $\cdot$ Climate change adaptation $\cdot$ Institutions

\section{Introduction}

\section{Agriculture in Kenya}

The agriculture sector is key to Kenya's economy. It accounts for $65 \%$ of the export earnings and provides the livelihood of more than $80 \%$ of the population. The sector employs more than $40 \%$ of the total population and about $70 \%$ of the rural population. In 2018, it contributed $34.2 \%$ of Kenya's gross domestic product (GDP) and an additional $27 \%$ through linkages to other sectors such as manufacturing, distribution, and services (Food and Agriculture Organization (FAO) 2020; Kenya National Bureau of Statistics (KNBS) 2019; Ministry of Agriculture, Livestock and Fisheries (MALF) 2020). The climate of Kenya varies from tropical along the coast to arid in the interior. The weather in Kenya is generally sunny year-round, with the main rainy seasons being from March to May and from November to December (International Coffee Organization (ICO) 2019a). The topography rises from the coastal plains to the eastern edge of the East African Plateau and the Great Rift Valley. The highest altitude is in the central region and temperatures of $15{ }^{\circ} \mathrm{C}$ compared to the coastal region with temperatures of $29^{\circ} \mathrm{C}$ (UNDP 2020). The Agriculture in Kenya is 98\% rain fed and highly sensitive to changes in temperature and rainfall. Studies indicate there will be a $20 \%$ decrease in rainfall by the year 2030 (Government of Kenya (GoK) 2015). Temperatures are projected to increase $1.2-2.2^{\circ} \mathrm{C}$ by 2050 in addition to increase in frequency and intensity of heavy rainfall, increase in severity of dry spells and duration of heat waves, and 16-42 cm rise in sea level (United States Agency for International Development (USAID) 2018). Since the early 1960s, both minimum and maximum temperatures have been increasing. The minimum temperature has risen generally by $0.7-2.0^{\circ} \mathrm{C}$ and the maximum by $0.2-1.3{ }^{\circ} \mathrm{C}$. There has been increased variability of rainfall from year to year and during the year. Extreme weather occurrences such as droughts and floods have become frequent and intense, leading to crop failures. 
The adverse impacts of climate change are compounded by human factors such as illegal encroachments and settlements, logging and livestock grazing, which exacerbate deforestation, land degradation, and desertification. Forest cover in Kenya, for instance, has fallen from $12 \%$ in the 1960 s to less than $2 \%$ in 2010 . Kenya has a landmass of about $582,350 \mathrm{~km}^{2}$ with $17 \%$ being arable while $83 \%$ consists of arid and semiarid land (ASAL) (GoK 2010). The combination of deforestation to open up croplands, the extension of agriculture onto land with low potential, and the use of more basic farming techniques and technologies due to cost and capacity barriers make the current agricultural system unsustainable in the long term (Republic of Kenya 2018). This necessitates that farmers engage in activities to adapt to and mitigate climate change. Adaptation refers to actions that minimize negative impacts of climate change, including the social, environmental, and economic impacts while mitigation refers to activities that reduce, prevent, or remove greenhouse gas (GHG) emissions and therefore reduce climate change. These measures require that farmers engage in sustainable agriculture, which is defined as farming in a responsible manner while enhancing profitability, well-being of the people, and the environment for now and the future (Cameron 2017).

The MALF oversees agriculture in the country. The Agriculture and Food Authority (AFA) is a government agency under MALF and is responsible for the development, regulation, and promotion of scheduled crops (ICO 2019b). AFA is comprised of several directorates that are specific to particular crops and include the Tea Directorate and the Coffee Directorate. Tea, horticulture, and coffee are Kenya's main agricultural exports. Tea and coffee are, however, unique as they are predominantly grown by small-scale farmers. This necessitates the formation of farmer organizations to benefit from economies of scale and to navigate the labor and capital-intensive process from production at the farm to the sale of the finished products.

\section{Climate Change Policies and Regulations in Kenya}

Kenya recognizes the importance of climate change action and has policies and plans to enact adaptation and mitigation measures. These include the National Climate Change Response Strategy (NCCRS) of 2010, National Policy on Climate Finance (2015), the Climate Change Act of 2016, the National Climate Change Action Plan (NCCAP) 2018-2022, and the National Adaptation Plan 2015-2030. The Environmental Management and Coordination Act (EMCA) of 1999 is the framework law on environmental management and conservation. Under this Act, EMCA established various institutions including the National Environmental Management Authority (NEMA). NEMA is the principal instrument of government charged with the implementation of all policies relating to the environment, and to exercise general supervision and coordination over all matters relating to the environment (National Environmental Management Authority 2020).

The NCCRS is the main document that guides the Kenya government's climate change agenda. The main focus of the strategy is to ensure that adaptation and mitigation measures are integrated in all government planning, budgeting, and development objectives. It prioritizes agriculture as one of the vulnerable sectors 
of the economy. The NCCRS established that the institutions in place to govern climate change affairs were inadequate and recommended that a comprehensive climate change policy and related legislation be put in place. The Climate Change Act was subsequently passed in 2016 and provides for a regulatory framework for an enhanced response to climate change. The Climate Change Act pertains to all sectors of the economy and to the national and county level government in the 47 counties of Kenya. It aims to mainstream climate change responses into development planning, provide incentives and obligations for private sector contributions in achieving low carbon climate resilient development, promote low carbon technologies, facilitate climate change research, and enhance cooperative climate change governance between the national government and county governments.

The Act obligates the Cabinet Secretary responsible for climate change affairs to formulate a five-year NCCAP. In accordance with the Act, the NCCAP represents the national mechanism through which climate change will be addressed in Kenya, including the implementation of the Nationally Determined Contributions (NDCs). Kenya submitted its NDCs in 2016. The NCCAP 2018-2022 provides mechanisms for mainstreaming climate change into all sectors of the economy and in the County Integrated Development Plans (CIDPs). The initiatives undertaken through the NCCAP include the scale up of renewable energy technologies, clean energy solutions, improved water resource management, sustainable forest management and tree planting, climate smart agriculture, and agroforestry (GoK 2015). It prescribes measures and mechanisms for climate change adaptation and mitigation, and the review and recommendation of duties of public and private bodies on climate change. Climate change duties refer to the statutory obligations conferred on public and private entities to implement climate change actions consistent with the national goal of low carbon climate resilient development. NEMA monitors, investigates, and reports on compliance with the assigned climate change duties. The Act also provided for financial provisions through the Climate Change Fund, which is a financing mechanism for priority climate change actions and interventions (Republic of Kenya 2016). Kenya also has a Climate Smart Agriculture Strategy for 20172026, which has been used as a source of input for the development of NCCAP 2018-2022 (Republic of Kenya 2018).

\section{Tea Sector in Kenya}

Kenya is the third largest producer of black tea globally after China and India, and is the world's largest exporter of black tea, contributing over $20 \%$ of total world exports. The sector is therefore significant to the global and national economy. By 2012 the sector accounted for $17 \%$ of total export earnings and $4 \%$ of the national GDP (FAO 2015). In 2018, tea earnings amounted to Ksh.127.7 billion (KNBS 2019). Tea is grown on 236,000 ha with smallholders cultivating 142,000 ha and estates 93,000 ha. Tea production in 2018 was 493,000MT with 272,500MT from smallholders and 220,500 from estates (KNBS 2019). The tea sector contributes to 
environmental conservation through improved water infiltration, reduced surface erosion rates, and enhanced carbon sequestration.

Tea farming in Kenya is regulated by the Tea Act, Revised Edition 2012 [1960]. The Tea Directorate undertakes regulation and compliance of the tea industry, marketing and promotion of tea, the provision of technical and advisory services, and tea export guidelines. It facilitates research on all tea-related matters through the Tea Research Institute (TRI). All tea farmers are required to register with a factory as shareholders and to which they must supply the entirety of their production. Nearly all tea factories with small-scale farmer membership are shareholders in the Kenya Tea Development Agency (KTDA), a management company with several subsidiaries. Acreage per farmer varies from 0.25 to over 50 acres and most KTDA farmers grow on approximately half an acre of tea on average. Majority rely heavily on tea production for their livelihoods, which comprises over $60 \%$ of their total income. KTDA works directly with 611,000 farmers and indirectly impacts over four million people. A $2.5 \%$ management fee based on net price for services rendered is paid to KTDA Management Services and KTDA subsidiaries charge for their services separately. The government supports KTDA through guarantees for loans and support to extension services through the Ministry of Agriculture. The Kenya Tea Growers Association (KTGA) was established to promote the common interests of large-scale tea growers and is open to growers who maintain over 10 ha of tea. The large-scale tea sector, also referred to as tea plantation, includes both individual farmers and corporations, and accounts for about $40 \%$ of total tea production in Kenya (Kenya Tea Growers Association (KTGA) 2016). Challenges in the tea sector include declining prices, low yields, high production costs, low production diversification, low value addition, and a multiplicity of taxes and levies (Ngumo 2015).

The agro-climatic requirements of tea are temperatures ranging from $10{ }^{\circ} \mathrm{C}$ to $30^{\circ} \mathrm{C}$, ideally $0.5-10$ degree slopes, elevations up to $2,000 \mathrm{~m}$, acidic volcanic soils, well-distributed rainfall between the range of 1,200 and 1,400 $\mathrm{mm}$ annually, sufficient sunshine hours, and a mild climate. Tea in Kenya is grown in altitudes between $1,500 \mathrm{~m}$ and $2,700 \mathrm{~m}$ above sea level, receiving $1,200-1,400 \mathrm{~mm}$ of rainfall annually, which is spread throughout the year (FAO 2015). The agro-zones for tea production include the areas of Mount Kenya, Aberdare Range, Nyambene Hills, Mau Escarpment, Kericho Highlands, the hills of Nandi and Kisii, Mount Elgon, and Cherangani Hills (FAO 2015). Tea production in Kenya occurs all year round but the highest yields are in the rainy seasons in March-June and October-December. The tea supply is consistent throughout the year in both quantity and quality. Over $90 \%$ of tea from Kenya is handpicked, with only the top two leaves and a bud being picked for processing to ensure high quality. About 50 varieties of tea have been developed to suit the seven tea growing regions. The tea is grown without the use of agrochemicals as it is pest and disease free, and requires only fertilizer to replenish soil (TRFK 2010). Tea husbandry includes weeding, pruning, and fertilizer application. Pruning is ideally undertaken at the end of the peak-growing period, July to August, when the soil moisture is still adequate (East Africa Tea Trade Association 2020). The weather during this period is usually cold with light rains and enables pruning to occur without sun scorch. 


\section{Climate Change Challenges in the Tea Sector}

Tea production is highly sensitive to changes in growing conditions. These conditions are expected to be impacted by climate change (Change 2015). Climate changes include inadequate rainfall, a larger soil water deficit, unpredictable rain patterns, and temperature rise (Ethical Trade Partnership (ETP) 2011). Climate change causes low productivity and poor quality in tea. Drought reduces the yields of tea while changes in the reliability and predictability of rainfall distribution and patterns have negative effects on tea yields and quality. Hailstorms and frost damage tea leaves and extreme temperatures suppress yields. High temperatures for example lead to decreased yields, reduced quality, high evaporation, reduced water content in the tea, dry weather pests, aggressive weed growth, weeds found in low country appearing in mid and up country poor bud break, bud scorch, stem and collar canker, wood root, leaf and bark desiccation. Excessive rain causes spread of fungal diseases, wet weather pests, and poor drainage in low-lying areas, heavy soil erosion that results in reduced water holding capacity, poor soil nutrients, and poor bud break and shoot development. Increase in extreme weather causes crop damage and failure due to events such as droughts, hail, storms, floods, frost, and landslides. Climate change also reduces productivity of subsistence crops which reduces food security (International Trade Center (ITC) 2014; Prematilake 2014). Due to climate change, the current areas of production are becoming unsuitable for tea production due to the risk of increasing temperature and increasing pests and diseases (ITC 2019; USAID 2018). A study by the International Center for Tropical Agriculture (CIAT) of climate change impacts on tea production in Kenya up to 2050, estimated that with increasing temperatures and rainfall, optimal areas for tea production will decrease, and production will have to shift to higher altitude areas, moving from around $1,500 \mathrm{~m}$ to 2,000 $\mathrm{m}$ above sea level (Ethical Tea Partnership 2011). A study by TRI indicates that in 2012, almost one-third of the harvest was lost (Omondi 2015). Incidences of severe and damaging frost that are attributed to climate change are becoming more common in Kenya. For example, the 2012 frost resulted in $30 \%$ tea crop loss in Nandi County (GoK 2015).

\section{Adaptation and Mitigation Measures by Small-Scale Farmers in the Tea Sector}

Tea planting is done through the planting of seedlings or more rarely, through the transplanting of a tree plant. Maturation of the tea seedling takes approximately 3 years, after which the tree plant continues production for decades. Adaptation to climate change can therefore not be carried out through adjusting the planting date. Adaptation measures can however be taken through adjusting the timing of tea husbandry activities such as pruning and fertilizer application, to climate change. Toward addressing issues on climate change, TRI is developing new technologies including environmental conservation efforts and development of improved tea varieties. TRI conducts research aimed at improving planting material, husbandry, 
yields, quality, and disease and pests control. It also provides advisory services to the growers on specific problems encountered in tea cultivation. The TRI has developed over 914 improved clones, of which 51 clones have been selected for consistent superiority in yield and quality. Thirteen of these clones yield between 5,000 and $8,000 \mathrm{~kg}$ of processed tea per hectare annually. These yield levels are some of the highest in the world and are three times the average yields of unimproved tea varieties. It has also developed a new tea clone - "Purple tea." According to the Kenya Agriculture and Livestock Research Organization (KALRO), the TRI began research on the "Purple Tea" cultivar over 25 years ago, and in 2011, the Tea Directorate began encouraging farmers to plant it. It is drought, frost, disease, and pest resistant. It has wide adaptability and is suitable for all designated tea-growing regions (KALRO 2020). Production of tea varieties such as purple tea, which is more resistant to climate variability than green tea, is a climate adaptation measure with the potential for higher income for tea farmers. Kimtai (2019) did a study aimed at establishing the rate of adoption of purple tea farming, determining the socioeconomic factors that hinders adoption and determining the role of purple tea farming for carbon sequestration. The purple variety had higher production than green tea and fetched higher prices. It was more resistant to drought, frost, hailstone, pests, and diseases. It was therefore highly rated for impacts of climate variability and change. Constraints to farming purple tea included availability of land, extension services were low particularly to farmers with the least acres of land (two acres), lack of training, poor access to credit, and limited market channels. The adoption of purple tea was however positively influenced by factors such as requiring little investment, higher income level, less risk on crop failure, and availability of labor.

Further adaption strategies include selection of the most suitable areas for tea growing, no expansion of new planting or replanting in low production areas, crop diversification in low production areas, efficient management of soil and water resources, catchment protection, riverbank protection, soil water conservation, crop insurance, use of drought tolerant cultivars, rainwater harvesting, and establishment of shade trees. Shade management particularly in the low and mid country reduces ambient temperature and prevents sun scorch. Other benefits of shade trees include carbon sequestration, improved net assimilation of tealeaf, reduced weed growth, additional organic matter from leaf litter and minimized wind damage, reduced frost, and reduced soil erosion (Ethical Tea Partnership 2011; Omondi 2015; Prematilake 2014). Tree planting also reduces frost and prevents soil erosion.

Several key partnerships enable the tea sector to adapt to and mitigate climate change. KTDA is involved in partnerships geared toward sustainable agriculture including climate change adaptation. One of its key partners has been Unilever, which is a multinational corporation with tea estates in Kenya and is also a major buyer of tea sold by KTDA. Unilever established a Sustainable Agriculture Programme in 1999. In 2007, it launched a partnership with the KTDA to enable Kenya's small-scale tea farmers acquire the certification standard set by the Sustainable Agriculture Network (SAN), which is a global coalition of environmental organizations. Factories and the KTDA trained farmers through Farmer Field Schools and Rainforest Alliance certification. Selected smallholder farmers are 
trained and they in turn instruct other farmers. Each lead farmer reaches an additional 300 farmers to ensure compliance with the SAN Standard required for Rainforest Alliance certification. KTDA in partnership with Unilever and IDH (the Dutch Sustainable Trade Initiative) has certified all the factories to the Sustainable Agriculture Network standards. Both farms and factories must meet the necessary requirements to receive Rainforest Alliance certification. By mid-2016, all of Kenya's smallholder tea farmers had met the Rainforest Alliance certification standards, and Unilever's Lipton brand was selling 100\%-certified tea. Other major tea brands also began purchasing certified tea (Cameron 2017). The replicability, scale, and local leadership component of this system could serve as a model for developing participatory climate change adaptation plans (Moroge 2012). By March 2019, all 69 KTDA-managed tea factories were Rainforest Alliance certified and 21 tea factories were Fair Trade certified. Other certifications obtained by tea producers and factories included UTZ, Kosher, and Ethical Tea Partnership (ETP) (IISD (International Institute for Sustainable Development) 2019).

This success is attributed to several factors. Key among these is that Unilever, which has a large market share in Kenya, made the decision to purchase only tea that was Rainforest certified. Tea production is linked to global rather than domestic demand, with more than $95 \%$ of tea produced in Kenya is exported. Other factors include the strong regulation of the tea sector by the government including the registration and licensing of factories by the Tea Directorate. Kenya's tea industry is also highly concentrated both geographically and structurally with KTDA accounting for $60 \%$ of the market. KTDA's structure is highly integrated with strong links between farmers and factories (Cameron 2017). Unilever was also part of the development of the Cool Farm Tool, a calculator of GHG emissions that is freely available for use by farmers. In collaboration with the Kenyan government, it has been using it to quantify carbon within its plantations (Ellis et al. 2013).

The World Bank (WB) is also a key partner in climate adaptation in the tea sector. It announced during the March 2019 Nairobi Summit that an Emission Reduction Purchase Agreement (ERPA) would be signed between the Carbon Initiative for Development (Ci-Dev) trust fund, with WB acting as trustee, and KTDA Power Company Ltd. (KTDA Power). The contract aims to purchase carbon credits from small hydropower plants that provide power to 350,000 smallholder tea farmers and 39 of their regional tea factories in Kenya (Africa Times 2019). ETP, an alliance of tea packers working toward the sustainability of the tea sector, is another key partner. They started work in Kenya in 2010 and implemented a Climate Change Adaptation Program with GIZ, a German development agency. ETP utilized technology developed by its partners, such as Cafedirect Producers' Foundation, which developed a tool called WeFarm, an SMS platform for farmers (Budsock 2015). ETP also created a partnership with ITC and other nongovernmental organizations and founded a project to help farmers in climate change adaptation and mitigation. The program trains farmers and tea factory managers in carbon standards compliance, conservation and management of water, soil conservation, and use of biogas instead of wood. A partner factory, Makomboki Tea Factory that was using 2,000 cubic meters of wood per month as fuel for drying tea, changed to alternative energy sources. This 
included sawdust, rice husks, biomass, macadamia, and cashew nut shells and briquettes made from sawdust and rice husk. The new initiative saved more than 30,000 trees while lowering operational costs of that factory by 20\% (Omondi 2015).

Multilateral partnerships are particularly effective in adaptation strategies. An example is the "Upscaling and Embedding Sustainability for Smallholder Tea Farmers," which is a collaborative initiative by KTDA Management Services (KTDA-MS), Unilever, and IDH - the Sustainable Trade Initiative. More than 85,000 (about $15 \%$ of 560,000 farmers) small-scale farmers had been trained by 2015 on Sustainable Agricultural Practices under a farmer field School (FFS) program (Cameron 2017). Another multilateral collaboration is between Germany, China, and the Food and Agriculture Organization (FAO), which was formed with the aim of promoting sustainable agricultural development and combating climate change in Kenya. This is through a project on carbon-neutral tea value chains. Germany through GIZ has been working with the KTDA, the Ethical Tea Partnership (ETP) among others in an integrated development partnership with the private sector to increase energy efficiency in all the factories to save GHG emissions and increase income of the farmers (Sino-German Center for Sustainable Development 2019). KTDA in 2015 signed a loan for Ksh.5.5 billion for the construction of seven small hydropower projects. The loan agreement was with the International Financial Corporation (IFC) which is a member of the World Bank, in partnership with other organizations including the Global Agriculture and Food Security Program (GAFSP) the French Development Institution (Proparco, the Netherlands Development Finance Company (FMO)). The expected reduction of reduce Kenya's carbon footprint from using hydropower is approximately 63,000 tons of carbon dioxide equivalent per year. On average, tea factories spend approximately Ksh. 30 million to Ksh. 65 million each per year on electricity (KTDA 2015). The hydropower plants have a total installed capacity of 16 megawatts and will provide captive power generation with the excess energy being sold to the state-owned power company. The farmers provided $35 \%$ equity on the loan via green leaf delivery, making it perhaps the first initiative in the world in which a farmer-owned institution is undertaking a renewable energy project of such a scale (IFC 2016).

KTDA Foundation, a nonprofit charity, also engages in environmental sustainability and climate change. Programs under climate change focus on promoting climate change mitigation, adaptation, and resilience building among smallholder tea farmers. In partnership with factories it has established over 31 indigenous, exotic, and fruit tree nurseries. Over 2.4 million trees have been planted in farms, major water catchment areas, and public forests. It is also undertaking an environmental conservation campaign for schools. Farmers are encouraged to adopt clean, renewable energy through promotion of and access to clean and renewable energy such as energy saving stoves, solar lighting products, and biomass. Adaptation measures include planting tea bushes along hill contours to reduce soil erosion. Seedlings from KTDA nurseries (commonly native species) are distributed throughout the local community for planting along farm boundaries, as buffers for waterways and forests, and to create small forest patches on farms. These native trees store carbon, stabilize the tea microclimate, and increase soil fertility. Planting native trees 
on steep slopes or degraded lands can also reduce vulnerability to heavy rains or prolonged droughts which creates resiliency to extreme weather. The KTDA is working to secure its own sources of sustainable fuel by acquiring land and encouraging its farmers to grow woodlots. Eucalyptus is commonly planted for fuelwood in the region. However, eucalyptus takes up large amounts of water, and KTDA and Rainforest Alliance are supporting farmers' efforts to replace eucalyptus in buffer zones with indigenous trees.

Although tea is on the "receiving end" of climate change, it also exacerbates it through deforestation. The common processing method of tea used in Kenya is the Cut Tear and Curl method, known as CTC. This involves the tea leaves going through a process of cutting, tearing, and curling, followed by oxidation and drying. The drying is often carried out using wood fuel due to the high price of electricity. Tea manufacturers are, however, gradually utilizing renewable energy alternatives such as electricity generation through micro-hydro plants to reduce energy costs and potentially generate further revenues by selling surplus electricity back to the national grid. Other mitigation measures include the use of biomass waste to power the water boiler systems. Gravity-powered ropeways are used by Finlay's, a multinational company, in some of its tea plantations. The KTDA also requires factories to acquire open land in order to plant seedlings and grow trees as a sustainable source of firewood. This saves money on the purchase of firewood or alternative fuels and could potentially generate revenues from carbon trading if the planted forests are managed sustainably. Varieties of tea other than Black CTC tea undergo a less emission-intensive process, as the wilting and CTC process are not required. Black CTC tea is manufactured by all 69 factories while only ten process black orthodox tea and four process other specialty tea.

\section{Coffee Sector in Kenya}

Kenyan coffee is grown on an estimated total area of 115,570 ha in 32 of 47 counties in the country. The sole type of coffee produced in the country is Arabica, which is planted during the rainy season from April to October with two harvest periods, April to June and October to December. Production is enabled by a combination of deep red volcanic soils, high altitude, rainfall, and moderate temperatures. The sole type of coffee grown in Kenya is Arabica. Coffee is grown in the high potential areas between 1,400 and 2,200 $\mathrm{m}$ above sea level, with temperature ranging from $15^{\circ} \mathrm{C}$ to $24{ }^{\circ} \mathrm{C}$, in red volcanic soils that are deep and well drained. Over $99 \%$ of Kenyan coffee is Arabica, whose main varieties are SL 28, SL 34, K7, Ruiru 11, Batian, and Blue Mountain (ICO 2019a). Coffee is an evergreen shrub and is therefore an important contributor to carbon sequestration, effective in stabilizing soils and permits the preservation of much of the original biodiversity in planted areas (ICO 2019 b). The coffee sector contributes annually an average of US\$230 million in foreign exchange earnings and is ranked as Kenya's fourth most important export, after horticulture, tourism, and tea. In 2018 coffee earnings amounted to Ksh. 14.8 billion. The value of coffee as a percentage of all export goods represented $5.5 \%$ in 
2017, while its share of GDP was $0.22 \%$. The coffee industry contributes an average of Ksh. 23 billion per year in foreign exchange earnings, ranking fourth after tourism, tea, and horticulture (ICO 2019a). Coffee is grown on 115,600 ha, 90,000 ha by smallholders and 25,000 ha by estates. Production was $41,400 \mathrm{MT}$ with 30,000MT from cooperatives and 11,000MT from estates (KNBS 2019). In 2017/18, the major importing countries of Kenyan coffee were Germany, the USA, Belgium, and the Republic of Korea, who imported about $58 \%$ of Kenya's coffee. Thirty-two of the 47 counties in Kenya are coffee producers (ICO 2019a).

Kenya has about 700,000 coffee farmers and about $99.63 \%$ have less than five acres. All coffee farmers with less than five acres are mandated to cooperative membership. There are between 500 coffee cooperatives (ICO 2019a) and 651 coffee cooperatives (KNBS 2019). Each coffee cooperative has factories where farmers deliver coffee berries for processing. At the factory, the coffee berries undergo pulping, which is a process of washing and drying, which results in "parchment." Parchment is then delivered to a coffee miller who further processes and grades the coffee, resulting in the "green" or "clean" coffee which is then sold by marketers at the Coffee Exchange through auctioning. Cooperatives also have the option of selling coffee directly to buyers without going through the auction. The Coffee Directorate is mandated to develop, promote, and regulate the coffee industry in Kenya. The Coffee Research Institute (CRI) conducts research in all areas of production, processing, and marketing of coffee. The global organization for coffee is the International Coffee Organization (ICO). It is comprised of member governments who represent $98 \%$ of world coffee production and $67 \%$ of world consumption. One of its objectives is to encourage members to develop a sustainable coffee sector in economic, social, and environmental terms (ICO 2019b).

\section{Climate Change Challenges in the Coffee Sector}

It is estimated that half the world's coffee-producing land will be unsuitable for coffee production by 2050 (Bunn et al. 2015; CIAT 2011). Other estimates indicate that the area unsuitable for production could be as high as $88 \%$ in Latin America (Worland 2018). Climate change caused by changing rainfall patterns and rising temperatures is affecting coffee production in several ways: directly through negative effects on the coffee plant and indirectly by altering the population dynamics and incidence of coffee pests and diseases (Jaramillo 2013). Rising temperatures will especially damage the Arabica bean, which accounts for about two-thirds of global coffee production, but whose production is limited to subtropical highlands in Brazil, Central America, and East Africa (Cameron 2017). This narrow region of the tropics is known as the coffee belt, and stretches from Central America to Sub-Saharan Africa to Asia (Worland, 2018). Rising temperatures will bring drought, increase the range of diseases, and kill large swaths of the insects that pollinate coffee plants (Worland 2018). Recent trends indicate that coffee growing is shifting from traditional optimal growing zones to higher altitudes. In traditional growing zones random flowering patterns and differences in berry growth stages has resulted in 
difficulties in disease and pest management, harvesting, and processing (Daily Nation 2012).

The effects of climate change in Kenya include unreliable and erratic rains with shorter seasons (ICO 2019b). Changing rainfall patterns affect the flowering of the coffee plants which impacts the whole production cycle. The altered flowering pattern with coffee berries at different stages of maturity poses a challenge in disease management, insect management, and harvesting (Ethical Tea Partnership 2011; Mugo 2016; Mwaura 2010). Extremely heavy rains lead to higher erosion levels, resulting in loss of soils, leaching of nutrients, and consequent soil infertility. On the other hand, the dynamics of incidence of coffee pests and their management are evolving rapidly due to changing climatic conditions. The changing environment is also posing challenges to patterns of cherry ripening and drying of parchment because of unpredictable rainfall patterns (ICO 2019b). Changing rainfall patterns cause uncertainty regarding the timing of fertilizer application and the drying of parchment. Most coffee growing zones in central Kenya, particularly Kiambu and Murang'a, are no longer suitable for the crop due to rising temperatures (Kamau 2017). Intermittent rainfall in the 2007/08 crop year caused a severe episode of Coffee Berry Disease that cut Kenyan output by $23 \%$ to 42,000 MT. This happened because farmers were not able to spray the crop on time (Mwaura 2010). Climate variability and its effects is however not a "new" problem, as evidenced by research shortly after Kenya's independence. This is illustrated by a 1969 journal article by Nutman and Roberts, titled "Climatic conditions in relation to the spread of coffee berry disease since 1962 in the in the East Rift Districts of Kenya." (F.J. Nutman \& F.M. Roberts 1969)

\section{Adaptation and Mitigation Measures by Small-Scale Farmers in the Coffee Sector}

The Coffee Directorate in collaboration with stakeholders provides capacity building to the counties' agricultural staff and other value chain players. The collaborating private agencies include Technoserve, Solidaridad, certification bodies such as UTZ, 4C, and Fairtrade, and management services providers. CRI develops technologies, releases new coffee varieties, and carries out research on disease and pest management, while the Ministry of Agriculture sets policy guidelines (ICO 2019b). The Coffee Research Foundation (currently CRI) started a program in 2012 to help farmers reverse the effects of global warming and boost coffee production. Farmer sensitization clinics were held and farmers were encouraged to plant indigenous trees to provide shade and to practice water harvesting (Daily Nation 2012). The CRI has made various recommendations on approaches toward environmentally sustainable coffee production systems. One approach is integrated farming, in which mulching, conservation agriculture, organic fertilizers, and use of bio-stimulants are recommended. Other measures include the use of suitable shade trees and the adjustment of spraying programs to cope with changing trends in the manifestation of coffee pests and diseases (ICO 2019a). Most Kenyan coffee is grown without 
shade, but shaded coffee is becoming increasingly popular in order to mitigate the effects of climate change, although quantifying the area under shade has not been done. Research is ongoing to determine the appropriate shade trees (ICO 2019a). Research shows that biodiverse shaded coffee is far more resilient and productive than coffee grown in monoculture. Shading coffee therefore improves the resilience of agro-ecosystems. Shade trees protect plants from microclimate variability, the effects of lower precipitation and reduced soil water availability, and reduce high solar radiation. It also improves soil fertility, protects coffee from insect pests, and provides economic benefits for farmers (Jaramillo 2013).

The need to develop disease-resistant coffee varieties was felt in early 1971 and breeding programs were initiated whose optimal outcome was the cultivar Ruiru 11 (Njoroge 1991). The CRI currently has developed two improved varieties of coffee - Ruiru11 and Batian. The improved varieties are resistant to Coffee Berry Disease and Leaf Rust Disease, thus lowering the use of agrochemicals and reducing production costs. The CRI estimated that the production cost of the traditional variety is four to five times more than Ruiru 11 and Batian. Over 300,000 farmers are estimated to have planted the new varieties (ICO 2019a). The traditional variety of coffee grown is SL-28. Other Arabica varieties include SL-34, K7, and Blue Mountain. A study of the coffee sector in Nyeri County showed that $50 \%$ of farmers in certified coffee cooperatives and $57 \%$ in the noncertified cooperatives had only the traditional SL variety of coffee on their farm. An additional $45 \%$ in the certified and 39 per in the noncertified had other varieties in addition to the SL (Okech 2019). It therefore means that less than 5\% had the disease and drought resistant varieties exclusively on their farms. Incentives therefore need to be provided to encourage planting of new varieties, beyond the step of providing free seedlings.

The International Coffee Organization (ICO) has pilot projects in Africa and Latin America to address climate change by assisting coffee farmers use environmentally friendly technologies. These include building the capacity of institutions, improving access to credit and risk management mechanisms, reducing vulnerability to income volatility, and promoting gender equality. It also engages in long- and short-term adaptation strategies as well as mitigation strategies (ICO 2019b). Several organizations including private companies involved in coffee production and marketing have taken the lead in climate change adaptation and mitigation in the coffee sector. The World Coffee Research (WCR), a consortium supported by major coffee retailers, distributors, and exporters, has an $\$ 18$ million coffee-monitoring program that covers 1,100 farms in 20 countries including Kenya. It conducts farmer training, provides technical assistance, and is testing coffee varieties and adaptive farming methods (Worland 2018). Since 2013 Starbucks has support centers in nine countries and a 10-year, $\$ 500$ million investment fund that supports sustainability programs, including adaptation training for farmers and the testing of new coffee varieties (Worland 2018). Sangana Commodities Ltd and GIZ implemented a three-year project creating a link between coffee smallholders and carbon markets, and developing a verifiable and voluntary climate change module, which can be integrated into the existing 4C's standard (ETP 2011). 
Sustainability standards in the coffee sector are geared toward sustainable agricultural practices, which include adaptation and mitigation measures. Certification in the coffee sector is, however, not as extensive as in the tea sector. In Nyeri County, which is a leading coffee producer, Fairtrade was the most common certification with at least 12 of the 23 cooperatives having received this certification. The earliest reported Fairtrade certification in the cooperatives was from 2006. At least seven cooperatives had obtained Rainforest Alliance certification and four had acquired 4C certification. Benefits of certification included payment of premiums and improved quality and quantity of coffee. Challenges included difficulty of maintaining certification as it was involving and expensive. This is illustrated by the example of an estimated Ksh. 400,000 for certification and renewal, with additional costs of up to Ksh. 1,000,000. Enforcing requirements as well as nonconformity to requirements was also costly. Certification organizations also did not source for markets and the cooperatives therefore used the conventional marketing channels, which were viewed as opaque (Okech 2019).

\section{Recommendations and Conclusion}

Tea and coffee are essential to farmers and other Kenyans as a source of livelihood, to the government as a contributor to GDP and foreign exchange and to the commodity chain players such as marketers and retailers. Tea and coffee also contribute significantly to climate change mitigation. Climate change, however, threatens to disrupt the production of these crops and by extension the economy of Kenya and the livelihoods of those who depend on it. Continued and increased uptake of climate adaptation and mitigation measures is critical for the sustainable farming of tea and coffee. Climate change can worsen the socioeconomic condition of farmers and conversely fragile socioeconomic conditions can exacerbate climate change. Various measures can be taken to increase the adaptive capacity of smallscale tea and coffee farmers.

\section{Farmer Empowerment}

Farmers are rational economic actors and farming has to be profitable for adaptation and mitigation measures to be implemented. Climate adaptation and mitigation activities such as uptake of improved crop varieties are carried out in view of perceived economic benefits and particularly for the most vulnerable, in view of immediate economic benefits. Activities such as the adaptation of improved crop varieties can be neglected due to small land size and the resultant "lost" while the new variety matures to the point of harvest. Other measures such as water harvesting may require capital expenditures whereby the capital is either unavailable or the returns to investment are deemed uneconomical. Interventions that deal with commodity chain weaknesses that reduce profitability are critical. Profitability of farming is the largest incentive to adopting sustainable agricultural practices. Increasing the 
adaptive capacity of tea farmers therefore requires farmers' economic empowerment. It is essential that stakeholders provide incentives for the implementation of measures whose returns are long-term or not tangible. This could include measures such as insurance for climate-related crop losses and a minimum guaranteed price per kilogram. Farmers also need to be politically empowered as decisions in farmer organizations are often made by elected representatives. Civic awareness is therefore an integral component of farmer empowerment. Social empowerment majorly revolves around gender. Men predominantly own land but women provide $60 \%$ of the labor on the farms and in the wet mills (ICO 2019b). Women therefore need to be major actors in activities involving climate change adaptation and mitigation. When they are not empowered, especially in terms of access to resources, various adaption and mitigation activities may not be implemented.

\section{Strengthening of Institutions}

The common features of the tea and coffee sector in Kenya is that both are cash crops, grown majorly for export and production is predominantly by small-scale farmers. Profitable production therefore requires that farmers organize so as to share costs. In the tea sector, the KTDA is the primary agency through which farmers produce process and market their tea. In the coffee sector, coffee cooperatives are the primary and mandated vehicle for production, marketing, and processing. However, there are coffee farmers with more than five acres who choose to remain in cooperatives due to economies of scale. Institutional capacity therefore has a large influence on farmers' activities, including those related to climate change adaption and mitigation. Lack of institutional capacity in farmer-owned organizations or institutions that support farmers can reduce productivity and profits and therefore constrain farmers' adaptive capacity. The average age of tea and coffee farmers is over 50 years and this further constrains the availability of alternative livelihoods. Unlike the tea sector where almost all small-scale tea farmers operate within the institutional structure of KTDA, coffee cooperatives are not homogeneous. For example, coffee payments for the 2017/18 year varied from Ksh. 9 to Ksh. 105/kg of coffee cherry (exchange rate in this period was approximately one USD to Ksh. 100-103). While there are climatic and soil-type differences, the differing payments were also within the same region. In Nyeri County, which is a leading coffee producer, the payment range was between Ksh. 12.75 and Ksh. 105. This points to institutional constraints at the cooperative level, although constraints occur across the coffee commodity chain. The challenges facing the coffee sector are well documented. Toward this end, a Coffee Taskforce was created to investigate the challenges and make recommendations for sectoral improvement. The tea sector has also encountered various institutional challenges. In January 2020, the president directed that the KTDA be restructured for the benefit of tea farmers (Cheruiyot 2020). The organizations that farmers engage in and the institutions within which they operate can either facilitate or constrain the activities of farmers, including those pertaining to climate change adaptation and mitigation. 


\section{Collaborations and Partnerships}

Climate change adaptation and mitigation requires the long-term involvement of all actors in the commodity chain including the consumers. Stakeholder mapping is necessary, whereby a list of relevant groups, organizations, and people who can collaborate in climate change adaptation and mitigation can be invited to collaborate towards these measures. These stakeholders include the International Coffee Organization, the Tea and Coffee directorates, agricultural institutions and departments, producer organizations, certification organizations, technical support providers, financial institutions, and supply chain actors including processors, marketers, and retailers. Research, information, and best practices on sustainable agricultural practices and on measures to streamline the commodity chain can be enhanced and widely adopted through collaboration.

\section{Certification}

The 2017 SAN Standard aims to support farmers in advancing sustainable livelihoods, improving farm productivity, and becoming more resilient to climate change. Changes of note include climate-smart agricultural practices. These are built into the standard to help farmers address climate change risks. The effect of irregular rainfall, changing temperatures, and related increased pest and disease attacks can be reduced through soil conservation, water-use efficiency, and the conservation and restoration of natural ecosystems. The Standard is built on principles of sustainable farming including biodiversity conservation, improved livelihoods and human well-being, natural resource conservation, effective planning, and farm management systems (Rainforest Alliance 2019). The SAN Climate Module is an add-on for voluntary verification within the existing Sustainable Agriculture Network certification system. Farmers who achieve compliance with the module will be able to assess the risks posed by climate change to their farms and communities, analyze their practices to quantify and reduce GHG emissions, and increase the carbon levels stored on their farms through the restoration of degraded lands, reforestation, and improved soil conservation while also being able to better adapt to altered growing seasons and other conditions (Sustainable Agriculture Network 2011).

Fairtrade aims to help farmers become more resilient to climate change while giving consumers, retailers, and traders the opportunity to reduce their carbon footprint. Farmers can spend the Fairtrade Premium on climate change adaptation projects such as tree planting, irrigation, crop diversification, and clean energy. Farming communities can also benefit from access to carbon finance, which can be used in mitigation or adaptation activities (Fairtrade International 2015). While certification has numerous benefits, acquiring and maintaining of certification by coffee cooperatives and estates requires the collaboration and financial support of stakeholders.

Rainforest Alliance and Fairtrade are the major certification bodies in the coffee and tea sector in Kenya. Majority of the small-scale tea farmers in Kenya comply with the SAN Standard and have received Rainforest Alliance. This extensive 
certification can be largely attributed to the institutional arrangement of the tea sector. KTDA acts as the management agent for 69 factories, which comprise the vast majority of small-scale tea farmers in Kenya. In the coffee sector, however, more than 700,000 farmers are members of an estimated 500-650 coffee cooperatives. Certification depends on various factors including membership numbers, productivity levels, number of factories, cooperative leadership, and relationships with a multiplicity of commodity chain actors. While some cooperatives are certified by multiple certification bodies, others do not comply with any sustainability standard. Certification ensures the implementation of climate change adaptation and mitigation measures. Acquiring and complying with sustainability standards is therefore key for small-scale farmers.

\section{References}

Africa Times (2019) World Bank commits \$22.5 billion more to Africa for climate change. Africa Times. Retrieved 10 Dec 2019 from https://africatimes.com/2019/03/15/world-bank-commits22-5-billion-more-to-africa-for-climate-change/

Budsock A (2015) Ethical tea partnership - adapting smallholders to climate change. Retrieved 10 Dec 2019 from https://impakter.com/ethical-tea/

Bunn, Laderach, Rivera and Kirschke (2015) A bitter cup: climate change profile of global production of Arabica and Robusta coffee Climate Change 129:89-101

Cameron B (2017) Brewing a sustainable future: certifying Kenya's smallholder tea farmers, 20072017. Woodrow Wilson School of Public and International Affairs, Innovations for successful societies. Princeton University. Retrieved 10 Dec 2019

Change K (2015) World tea production and trade current and future development, Food and agriculture organization, trade and markets division. FAO, Rome

Cheruiyot K (2020) Uhuru orders for KTDA restructuring to save tea farmers. The Star. Retrieved 22 Jan 2020 from https://www.the-star.co.ke/news/2020-01-14-uhuru-orders-for-ktdarestructuring-to-save-tea-farmers/

Daily Nation (2012) New plan to help farmers reverse effects of climate change. Daily Nation. Kenya. Retrieved 10 Dec 2019 from https://reliefweb.int/report/kenya/new-plan-help-farmersreverse-effects-climate-change

East Africa Tea Trade Association (2020) Tea care and husbandry management. Retrieved from eatta.com

Ellis K, Lemma A, Mutimba S, Wanyoike R (2013) Low carbon competitiveness in Kenya. Policy brief, Overseas Development Institute. Retrieved 17 Jan 2020

Ethical Tea Partnership (2011) Climate change adaptation in the Kenyan tea sector. Report from the adaptation workshop held in Kericho on the 16th of May 2011. Retrieved from ethicalpartnership.org

Fairtrade International (2015) Climate change. Retrieved 2020 from fairtrade.net: https://www. fairtrade.net/issue/climate-change

FAO (Food and Agricultural Organization) (2020) Kenya at a glance. Retrieved from www.fao.org: http://www.fao.org/kenya/fao-in-kenya/kenya-at-a-glance/en/

FAO (Food and Agriculture Organization of the United Nations) (2015) Kenya's tea sector under climate change. An impact assessment and formulation of a climate-smart strategy, by Elbehri A, Cheserek B, Azapagic A, Raes D, Mwale M, Nyengena J, Kiprono P, Ambasa C. Rome, Italy

Government of Kenya (2015) Addressing climate change: success stories from Kenya. Ministry of Environment, Natural Resources and Regional Development Authorities. Government of Kenya. Retrieved 17 Jan 2020 
Government of Kenya (2010) National climate change response strategy. Executive Brief. Retrieved from environment.go.ke: http://www.environment.go.ke/wp-content/documents/com plete $\% 20$ nccrs $\% 20$ executive $\% 20$ brief.pdf

IFC (2016) Kenya's tea farmers taste benefits of hydropower. International Finance Corporation. Retrieved 9 Mar 2020 from ifc.org: https://www.ifc.org/wps/wcm/connect/news_ext_content/ ifc_external_corporate_site/news+and+events/news/impact-stories/tea-farmers-taste-the-bene fits-of-hydropower

IISD (International Institute for Sustainable Development) (2019) Sustainability and voluntary certification in the Kenyan tea sector. Developing an action plan to address opportunities and challenges. Report of the Meeting Held in Nairobi, Kenya, March 6, 2019. Retrieved 29 Apr 2020 from iisd.org

International Coffee Organization (2019a) Country coffee profile: Kenya. International Coffee Organization. International Coffee Council. Retrieved 17 Jan 2020 from http:/www.ico.org/ documents/cy2018-19/icc-124-7e-profile-kenya.pdf

International Coffee Organization (2019b) Developing a sustainable coffee economy. Retrieved 17 Jan 2020 from http://www.ico.org/sustaindev_e.asp

International Trade Center (2014) Mitigating climate change in the tea sector. ITC, Geneva. Retrieved from: intracen.org on 17 Jan 2020

Jaramillo JSM-O (2013) Climate change or urbanization? Impacts on a traditional coffee production system in East Africa over the last 80 years. (Hart JP, ed). PLoS ONE 8(1). Retrieved 17 Jan 2020 from https://journals.plos.org/plosone/article?id=10.1371/journal.pone.0051815

KALRO (2020) Purple tea. Retrieved from kalro.org: http:/www.kalro.org/tea/?q=Purple\%20Tea

Kamau G (2017) Coffee takes beating from rising global temperature. The East African. Retrieved 17 Jan 2020 from https://theeastafrican.co.ke/business/climate-change-effect-on-coffee/25603998982-giionx/index.html

Kenya National Bureau of Statistics (KNBS) (2019) Economic survey 2019. Economic survey, Kenya National Bureau of Statistics. Retrieved 10 Dec 2019 from www.knbs.or.ke

Kenya Tea Growers Association (KTGA) (2016) Kenya tea growers association. Retrieved 23 Apr 2020 from Kenya Tea Growers Association: ktga.or.ke

Kimtai R (2019) Adoption of purple tea farming as a coping mechanism to climate variability and change. A case study of Kericho County, Kenya. Masters thesis, Jomo Kenyatta University of Agriculture and Technology, Environmental Legislation and Management. Retrieved 17 Jan 2020

KTDA (2015) KTDA Signs Ksh. 5.5 Billion loan agreement to construct seven small hydropower projects. Retrieved 9 Mar 2020 from ktdateas.com: https://www.ktdateas.com/index.php/blogs/ item/49-ktda-signs-ksh-5-5-billion-loan-agreement-to-construct-seven-small-hydropower-pre jects.html

Ministry of Agriculture, Livestock and Fisheries (2020) Towards sustainable agricultural transformation and food security in Kenya 2019-2029. Government of Kenya. Retrieved 10 Mar 2020 from http://www.kilimo.go.ke/wp-content/uploads/2019/01/ASTGS-Full-Version.pdf

Moroge M (2012) In Kenya, tea growers adapt to climate change. Retrieved 10 Mar 2020 from rainforest-alliance.org: https://www.rainforest-alliance.org/pictures/kenya-tea-growers

Mugo I (2016) Global warming takes its toll on coffee production. Daily Nation. Kenya. Retrieved 10 Dec 2019 from https:/www.nation.co.ke/news/Global-warming-takes-its-toll-on-coffee-pro duction/1056-3461704-avbq99z/index.html

Mwaura HN (2010) Climate change affecting Kenya's coffee output. Retrieved 10 Dec 2019 from https://www.reuters.com/article/us-kenya-coffee-climate/climate-change-affecting-kenyas-cof fee-output-idUSTRE61A0WA20100211

National Environmental Management Authority (2020) Environmental Act (EMCA). Retrieved from nema.go.ke: http://www.nema.go.ke/index.php?option=com_content\&view=article\& $\mathrm{id}=24 \&$ Itemid $=163$

Ngumo D (2015) My experience in the tea sector. Retrieved from karuspace.karu.ac.ke

Njoroge J (1991) Management of hybrid Ruiru 11 [eleven] Arabica coffee - a review. Coffee Research Foundation, Ruiru. Retrieved 10 Dec 2019 from www.kainet.ne.ke/documents/man agement-hybrid-ruiru-11-eleven-arabica-coffee-review-1 
Nutman FJ, Roberts FM (1969) Climatic Conditions in Relation to the Spread of Coffee Berry Disease Since 1962 in the East Rift Districts of Kenya. East African Agricultural and Forestry Journal 35 (2):118-127

Okech AN (2019) Producer institutional arrangements in Kenya's coffee sector and their effect on economic benefits to farmers. PhD thesis. Department of Development Studies. Jomo Kenyatta University of Agriculture and Technology, Juja

Omondi D (2015) Climate change bites Kenyan tear farmers. Voices2Paris. Retrieved 10 Dec 2019

Prematilake K (2014) Climate change adaptation strategies for tea plantations. Tea Research Institute of Sri Lanka, Agronomy Division. Retrieved 17 Jan 2020

Rainforest Alliance (2019) What does rainforest alliance certified mean? Retrieved 11 Mar 2020 from rainforest-alliance.org: https://www.rainforest-alliance.org/faqs/what-does-rainforest-alli ance-certified-mean

Republic of Kenya (2016) The climate change act, 2016. Kenya gazette supplement. Government Printer, Nairobi

Republic of Kenya (2018) National climate change action plan 2018-2022. Ministry of Environment and Forestry. Government of Kenya

Sino-German Center for Sustainable Development (2019) Carbon-neutral tea value chains Germany, China and the FAO Join Forces with Kenya. Retrieved 9 Mar 2020 from https://sgcsd.org: https://sg-csd.org/news_events/20190328/

Sustainable Agriculture Network (2011) SAN climate module criteria for mitigation and adaptation to climate change. Retrieved from www.rainforest-alliance.org: https://www.rainforest-alliance. org/lang/sites/default/files/site-documents/climate/documents/SAN-Climate-Module-Januar y2011.pdf

UNDP (2020) Climate change adaptation. Kenya. Retrieved from adaptation-undp.org

USAID (2018) Climate risk profile Kenya. Retrieved from: climatelinks.org on 17 Jan 2020

Worland J (2018, July 2) Your morning cup of coffee is in danger. Can the industry adapt in time? TIME. Retrieved 17 Jan 2020 from http://time.com/5318245/coffee-industry-climate-change/

Open Access This chapter is licensed under the terms of the Creative Commons Attribution 4.0 International License (http://creativecommons.org/licenses/by/4.0/), which permits use, sharing, adaptation, distribution and reproduction in any medium or format, as long as you give appropriate credit to the original author(s) and the source, provide a link to the Creative Commons license and indicate if changes were made.

The images or other third party material in this chapter are included in the chapter's Creative Commons license, unless indicated otherwise in a credit line to the material. If material is not included in the chapter's Creative Commons license and your intended use is not permitted by statutory regulation or exceeds the permitted use, you will need to obtain permission directly from the copyright holder.

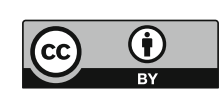

